\title{
Aznar, Hugo (2005) Comunicação Responsável - A auto-regulação dos media, Porto: Porto Editora.
}

Joaquim Fidalgo*

Hugo Aznar, reputado professor e investigador da Universidade Cardenal Herrera CEO (Valência, Espanha), é um dos mais destacados estudiosos contemporâneos da auto-regulação dos media - aqui se incluindo o jornalismo, mas não só. A sua obra Comunicación Responsable, originalmente publicada em 1998, conquistou mesmo o primeiro lugar na X Edição dos Prémios à Investigação sobre Comunicação de Massas, patrocinados pelo Conselho do Audiovisual da Catalunha. Comunicação Responsável, o título lançado em 2005 pela Porto Editora, é a tradução portuguesa deste livro - mais concretamente, de uma sua segunda edição, entretanto revista e aumentada. Ao longo de cerca de 270 páginas, Aznar percorre com detalhe os diversos mecanismos voltados para a auto-regulação dos meios de comunicação social (sejam os de iniciativa dos jornalistas, no seio de redacções concretas ou do grupo profissional no seu todo, sejam os de iniciativa das empresas mediáticas), focando-se em alguma medida na realidade espanhola, mas indo quase sempre para além dela, fornecendo elementos para a melhor compreensão da génese histórica e do desenvolvimento destes instrumentos destinados a contribuir para a existência de media cada vez mais livres, sim, mas também cada vez mais responsáveis.

É, aliás, na necessidade de conjugar adequadamente o binómio liberdade/responsabilidade que Hugo Aznar alicerça o imperativo da auto-regulação e a sua vantagem comparativa face a outros mecanismos ou processos, exteriores aos media, de regulação das actividades de comunicação pública. Como escreve logo no início, “[a] liberdade de expressão, da qual beneficiam os media, foi conquistada como um espaço de liberdade vedado à interferência do poder público. Pretender agora regular esse espaço de liberdade através da lei ou da intervenção estatal seria, em certa medida, contraditório face ao próprio processo de avanço histórico dessa liberdade” (p. 11). Se isto é assim, não é menos verdade que o funcionamento dos media em sociedades de livre mercado, como as nossas, pode fazê-los tributários de uma exclusiva lógica económica e empresarial, com isso correndo o risco de produzir "graves desvirtuações do sentido e da função que devem cumprir” (p. 10). E o discurso dominante, nas posições neoliberais que se vão disseminando hoje em dia, reclama uma total desregulação dos media - mas uma desregulação que, afinal, acaba por ser uma forma subtil de regulação, feita exclusivamente segundo a lógica do negócio e a 'mão invisível' do mercado.

\footnotetext{
* Professor de Jornalismo da Universidade do Minho. Membro do Centro de Estudos de Comunicação e Sociedade. Declaração de interesses: Joaquim Fidalgo é, juntamente com Manuel Pinto, o coordenador da Colecção Comunicação, da Porto Editora. (jfidalgo@ics.uminho.pt)
} 
Ora é na tentativa de ultrapassagem desta visão dicotómica que Aznar situa, então, a proposta auto-reguladora: uma proposta que não deixa os media exclusivamente à mercê dos critérios económicos e empresariais (sob pena de poderem esquecer as suas indeclináveis responsabilidades sociais), mas também uma proposta que procura preservá-los de uma intervenção do Estado que possa fazer perigar a sua irredutível exigência de liberdade. A auto-regulação, nas suas palavras, significa assim "uma deslocação do ajuste normativo dos media do Estado - e a sua regulação jurídico-administrativa - e do mercado - e a sua regulação económica - para a sociedade civil e a sua regulação ética" (p. 13). Pode, por este caminho, tornar-se "efectiva a exigência de responsabilidade que a sociedade reclama aos media sem o risco de restringir a liberdade dos mesmos, evitando ao mesmo tempo a amoralidade - ou imoralidade - própria do mercado" (ibidem).

É este um processo difícil e exigente, pois implica que os próprios protagonistas da actividade mediática - os empresários, os jornalistas, o próprio público, cada vez menos encarado como mero receptor passivo e mais como actor de corpo inteiro da relação comunicativa - assumam, livre e responsavelmente, o compromisso voluntário de velar pela promoção dos bens internos da comunicação, não deixando que a eles se sobreponham outros critérios ou interesses particulares. É, no entanto, segundo o autor, a forma mais correcta de "conseguir melhores meios de comunicação social, mais ajustados aos valores e princípios da comunicação” (p. 9). A implementação dos diferentes mecanismos de auto-regulação ("a tarefa pendente do jornalismo", como diz Aznar) contribui, com efeito, para "criar as condições para um exercício melhor e mais digno da actividade jornalística e para proporcionar à ética da comunicação uma eficácia real e uma presença social” (p. 18).

Feita uma introdução onde são definidos os conceitos básicos e discutidas algumas das dúvidas mais recorrentes sobre a auto-regulação dos media (designadamente a sua suposta falta de eficácia), o autor dedica um primeiro capítulo aos códigos deontológicos dos jornalistas - o mecanismo auto-regulador mais antigo e mais disseminado por variadíssimas latitudes -, falando-nos da sua história, do seu conteúdo (e das respectivas revisões, frequentes sobretudo nos anos 1990), da sua função e utilidade. Sem descurar a importância que tais documentos assumem, conclui, entretanto, que seria pouco correcto depositar neles todas as esperanças para a existência de meios de comunicação adequadamente auto-regulados: "Os códigos representam um primeiro passo iniludível, mas, no difícil caminho de construir um mundo da comunicação mais ético e comprometido com os valores humanos, fazem falta novos passos” (p. 60).

Estes “novos passos” são, depois, divididos por Hugo Aznar em três grandes áreas: a área das responsabilidades que, no domínio da auto-regulação, cabem às empresas de comunicação social e aos media enquanto tais (Capítulos II e III), a área do que compete especificamente aos profissionais dos media, seja enquanto grupo profissional alargado, seja enquanto colectivos específicos no espaço de uma redacção (Capítulos IV e V), e, finalmente, a área do que mais especificamente tem a ver com os públicos e com a sua participação activa nos processos mediáticos (Capítulos VI e VII). 
As tensões e contradições que podem atravessar o interior das empresas mediáticas - divididas entre o desejo de obter o maior lucro possível, enquanto empresas, e o propósito de prestar um serviço à sociedade, enquanto meios de comunicação social - reclamam delas, segundo o autor, a assunção de algum compromisso ético decorrente da sua especificidade (uma especificidade que tem a ver com a natureza muito particular do bem com que trabalham e que comercializam, ou seja, a informação). Dada esta infra-estrutura empresarial em que se exerce a actividade da comunicação pública, e em cujo contexto laboral se inserem obrigatoriamente os jornalistas, parece claro que as exigências éticas do processo comunicativo não podem ser deixadas apenas à responsabilidade dos profissionais: por muito autónomo que seja o seu funcionamento, os condicionalismos da actividade industrial e comercial implicam que a própria empresa assuma alguns princípios e regras neste domínio, se não quer entregar-se única e exclusivamente às lógicas económicas de mercado. Códigos internos de conduta (sejam dos meios, sejam da própria empresa como um todo), estatutos editoriais, livros de estilo, são mecanismos auto-reguladores que a empresa mediática pode adoptar, com a vantagem de que definem e adoptam normas de funcionamento para o interior mas, simultaneamente, tornam público e visível, para o exterior, um compromisso público com princípios e valores que colocam a exigência ética em lugar destacado. Aznar evoca, a este propósito, a Resolução 1003 do Conselho da Europa (datada de 1993), segundo a qual "as empresas de informação devem ser consideradas como empresas socioeconómicas especiais cujos objectivos empresariais devem ser limitados pelas condições que devem tornar possível a prestação de um direito fundamental" (p. 92).

Uma responsabilidade muito particular em matéria de auto-regulação é, entretanto, esperada dos próprios profissionais da comunicação social, no pressuposto de que eles dão corpo e voz ao direito fundamental (e universal) à liberdade de expressão mas, simultaneamente, devem dar resposta ao não menos fundamental direito de todos os cidadãos a uma informação completa, rigorosa, fiável e independente. O empenhamento dos jornalistas na criação de condições - legais, sociais, económico-laborais - que lhes permitam exercer adequadamente este ofício é um dos lados da moeda, sendo o outro, em contrapartida, a sua garantia de que a exercerão com respeito escrupuloso pelos direitos básicos de todos e com fidelidade aos princípios éticos e às regras deontológicas essenciais da sua actividade (da qual deverão, aliás, prestar contas ao público). A afirmação consequente do jornalismo como uma profissão - com o que tal implica de domínio aprofundado de um saber e um saber-fazer próprios, de organização em termos colectivos para o controlo da actividade pelos próprios pares, e de orientação por uma lógica de serviço desinteressado à comunidade - é considerada por Hugo Aznar um dos elementos essenciais para que os jornalistas desenvolvam uma cultura de exigência ética e de escrúpulo deontológico. Mas, como “o jornalismo não é uma profissão liberal no sentido habitual do termo" (p. 149), esta exigência ética e deontológica precisa de ser traduzida também em mecanismos auto-reguladores que, no interior concreto das redacções e das empresas, garantam, por um lado, o 
funcionamento dos profissionais em condições de mínima autonomia editorial (face, desde logo, aos critérios comerciais que coexistem nas estruturas empresariais em que trabalham) e, por outro lado, assegurem o controlo da sua actividade, para que ela não se desvie dos "bens internos" da comunicação pública. Estatutos de redacção e conselhos de redacção são exemplos de instrumentos que contribuem para a realização destes objectivos.

O edifício auto-regulador ficaria incompleto, no entanto, se nele não se desse também um lugar aos públicos - afinal, a razão última de ser do trabalho da comunicação social. A responsabilidade dos media é uma responsabilidade "para com" alguém e, nesse sentido, o imperativo de prestação de contas (ou accountability) à sociedade por aquilo que se faz, e como se faz, acaba por ser o corolário obrigatório de uma postura efectivamente responsável para além das meras boas intenções individuais. Mecanismos de auto-regulação que, mesmo decorrendo da livre iniciativa dos media ou dos seus profissionais, incorporam a voz e a opinião do público - como os provedores do leitor / do ouvinte / do telespectador, ou os conselhos de imprensa - desempenham, aqui, um papel importante e têm suscitado interesse crescente nos últimos anos. A ultrapassagem de uma concepção dos auditórios como meros receptores passivos e, pelo contrário, a sua consideração como parceiros centrais do processo comunicativo, como que fecha o círculo alargado das vontades auto-reguladoras e do seu empenho na constante melhoria da qualidade dos media. E é um passo que deve ser dado sem receios de interferências abusivas que alguma tentação corporativa dos jornalistas, ou a afirmação enfática do direito de propriedade dos empresários, por vezes dificulta. Isso mesmo esclarece Aznar no seu livro: “O papel do público não é determinar a linha editorial de um meio de comunicação social, mas exigir que essa linha se ajuste à promessa feita no momento adequado, através dos princípios [enunciados] e, da mesma forma, que sejam assumidas as responsabilidades, obrigações e valores associados ao bem que é difundido, ou seja, à informação e à comunicação” (p. 184).

Optimista quanto à atenção crescente que a proposta da auto-regulação dos media parece vir recebendo (no seio dos media e para além deles), o autor desta obra nem por isso deixa de encarar com prudência as expectativas que nela possam ser colocadas, no que tem a ver com resultados práticos. Insiste, isso sim, na bondade desta via enquanto alternativa vantajosa face a mecanismos reguladores impostos do exterior (cujos efeitos perversos potenciais não se cansa de apontar), deixando uma nota de confiança no desenvolvimento simultâneo de diversos mecanismos que concorram para este mesmo fim. A eficácia da auto-regulação, como sublinha, "não deve ser avaliada apenas pela eficácia isolada de cada um destes mecanismos, mas pela eficácia conjunta de pelo menos alguns deles" (p. 23). Insiste, assim, na "lógica de rede" com que devem ser encarados e promovidos os mecanismos de auto-regulação, com a convicção de que "a eficácia de cada um deles aumenta conforme a quantidade e variedade dos restantes, e cresce também com a complementaridade existente entre eles” (pp. 22-23). Ou seja: "Quanto mais mecanismos existirem, maior será o reforço mútuo e, portanto, maior será a eficácia de cada um e de todos eles em conjunto” (ibidem). 
Deixe-se, em complemento ao que aqui fica dito, uma última nota para destacar o trabalho de investigação e de divulgação desenvolvido por Hugo Aznar em outros domínios da comunicação, sempre com um grande empenho nas vantagens da autoregulação. Em Ética de la Comunicación y Nuevos Retos Sociales (Paidós, 2005), aborda com detalhe os códigos e recomendações existentes quanto ao tratamento de temas muito actuais como as catástrofes e tragédias humanitárias, o racismo, a imigração e a xenofobia, o terrorismo, a discriminação das mulheres ou a violência doméstica. Em Pautas Éticas para la Comunicación Social (Universidade Cardenal Herrera-CEU, 2005), fornece um conjunto de guias para os profissionais da comunicação no que tem a ver, sobretudo, com o tratamento das questões dos menores e com a repercussão dos media (em particular a televisão) na infância. E em Ética e Periodismo (Paidós, 1999), faz um levantamento exaustivo dos códigos, estatutos e outros documentos (entre eles os dimanados de organizações internacionais como a Unesco, o Conselho da Europa ou a Federação Internacional dos Jornalistas) orientados para a auto-regulação genérica dos meios de comunicação social. São exemplos de uma bibliografia já vasta que muito tem contribuído para colocar na agenda dos debates públicos - e nas preocupações dos profissionais - o desafio, difícil mas sem dúvida aliciante, da auto-regulação dos media. 